\title{
Biocontrol of Macrophomina phaseolina (Tassi) Goid causing charcoal rot disease in Lycopersicon esculentum L. by using multi species bacterial consortia
}

\author{
Pradeep Kumar $\times$ \\ Department of Botany and Microbiology, Gurukul Kangri University, Haridwar, Uttarakhand, India. \\ Sandeep Kumar \\ Department of Botany and Microbiology, Gurukul Kangri University, Haridwar, Uttarakhand, India. \\ R. C. Dubey \\ Department of Botany and Microbiology, Gurukul Kangri University, Haridwar, Uttarakhand, India.
}

\begin{tabular}{|c|c|}
\hline ARTICLE INFO & ABSTRACT \\
\hline $\begin{array}{l}\text { Received : } 28 \text { September } 2021 \\
\text { Revised : } 01 \text { November } 2021 \\
\text { Accepted : } 15 \text { November } 2021 \\
\text { Available online: } 19 \text { December } 2021 \\
\text { Key Words: } \\
\text { Pseudomonas } \\
\text { Azotobacter } \\
\text { Bacillus } \\
\text { Biological control } \\
\text { Macrophomina phaseolina }\end{array}$ & $\begin{array}{l}\text { Plant growth-promoting bacterial strains (LEP1-LEP31) were isolated from } \\
\text { rhizosphere of Lycopersicon esculentum L. (Tomato) and screened for their } \\
\text { plant growth promoting (PGP) activities. On the basis of morphological, } \\
\text { physiological, biochemical, carbon source utilization and molecular } \\
\text { characterization, these strains were identified as Pseudomonas sp., Azotobacter } \\
\text { sp. and Bacillus sp. For antagonistic activities all the strains were subject to } \\
\text { the chitinase activities by the development of clear halo around the inoculated } \\
\text { bacterial spots when loaded on chitin (0.2\%) supplemented mediumBased on } \\
\text { pot and field trial results of individual strains and consortium application, it } \\
\text { may be concluded that all the three strains i.e. Pseudomonas sp. LEP17, } \\
\text { Azotobacter sp. strain LEP21 and Bacillus sp. strain LEP25 showed plant } \\
\text { growth promoting effects. The growth promotion provided by these strains } \\
\text { was apparently related to improve shoot and root development, which resulted } \\
\text { in better nutrient uptake capability and suppression of plant pathogen. All } \\
\text { these three strains were superior in this regard because they provided the best } \\
\text { and most consistent effects on growth and yield of L. esculentum. All these } \\
\text { strains Pseudomonas sp. LEP17, Azotobacter sp. strain LEP21, Bacillus sp. } \\
\text { strain LEP25 and their consortium seems to be suitable for use as a plant } \\
\text { growth promoting and improvement of growth and yield of L. esculentum and } \\
\text { suppression of fungal phyto-pathogen M. phaseolina. }\end{array}$ \\
\hline
\end{tabular}

\section{Introduction}

Tomato (Lycopersicum esculentum L.) suffers from leaf blight, seedling blight, foliage blight, pre and several diseases caused by fungi, bacteria and post emergence damping off of crop plant, weeds viruses etc. One of the serious fungal diseases is the grasses and trees in tropical, subtropical and charcoal rot caused by Macrophomina phaseolina. This fungus survives in soil by microsclerotia produced during parasitic phase of life and survives in soil for several years. M. phaseolina is destructive soil borne plant pathogen of more than 500 plant species worldwide. Due to highly prokaryotic character of the mycelium, the fungi appear to be highly variable in nature. Charcoal rot is common disease caused by M. phaseolina among stem rot, collar rot, dry root rot, pod and stem rot, temperate range of $25-40^{\circ} \mathrm{C}$ (Dhingra and Sinclair, 1977). This fungus caused a serious damage and a great loss in crop yield every year throughout the world particularly in the tropical countries. Besides, it infects the seed that either failed to germinate or produce seedlings which do not survive. A wide variety of seeds carry the inoculums of pathogen inside their seed coat (Agarwal and Sinclair, 1997). Infection of M. phaseolina starts from movement of the pathogen from rhizosphere to the root surface.

Corresponding author E-mail: pradeepksaini@yahoo.com

Doi: https://doi.org/10.36953/ECJ.2021.22351

This work is licensed under Attribution-Non Commercial 4.0 International (CC BY-NC 4.0)

(C) ASEA 
After many steps including penetration pathogen establish itself inside the host tissue. Before penetration many activities can be seen such as sclerotia germination, hyphal growth, aspersoria formation and penetration through cracks inside the root surface done mechanically or through biological agents Aspersoria exert mechanical pressure to get entry inside the root tissue. The hyphae of M. phaseolina grow first intercellular in the cortex and then intracellular through the xylum tissue colonizing the vascular tissue. Establishment of $M$. phaseolina inside host tissue is done by joint action of substrate specific enzymes and a number of phytotoxins (Kumar et al., 2005). Tomato is a common plant with edible fruit cultivated all over India. The present research work is focused to screen tomato rhizosphere for plant growth promoting strains of Azotobacter, Bacilli and Pseudomonas with ability to reduce the incidence of fungal disease especially charcoal rot. Charcoal rot is a deadly disease caused by M. phaseolina. We will also analyze the application of biofertilizer or inoculum to increase productivity. Using plant growth promoting rhizospheric competent strains in co-culture and consortia with experimental pot trail and field trial.

\section{Material and Methods}

Isolation and characterization of rhizospheric bacteria associated with tomato roots

The survey of the study area will be done. The samples from different sites will be collected and transported to the lab under sterile conditions for further studies. The rhizospheric bacteria will be isolated using standard dilution technique according to Vincent (1970). These cultures will be examined for their morphological, physiological and biochemical characteristic according to Bergey's manual.

To evaluate bacterial isolates for their PGPR activities.

The isolates will also be screened for their plant growth promoting (PGP) activities including phytohormone $\left(\mathrm{IAA}_{3}\right)$ production, phosphate solubilization, HCN production, siderophore production etc. (Chandra et al., 2007), secretion of other volatile organic compounds (VOC's), Nitrogen fixation.

Antagonistic properties against Macrophomina phaseolina

In vitro antagonistic properties of the isolates shall be studied by dual culture method (Skidmore and Dickinson, 1976).

Molecular characterization of selected plant growth promoting isolates

Organisms from different biotypes will be selected for molecular characterization. Selected biotypes will be subjected for genomic extraction and amplification of $16 \mathrm{~S}$ rDNA. The amplified DNA will be sequenced and the data thus obtained will be used to search the similar sequences in primary databases. The sequences will be aligned using multiple sequence alignment programs and phylogenetic analysis will be performed.

\section{Studies on bacterial interaction for co-culture and consortia}

Bacterial interaction will be performed Skidmore and Dickinson (1976) and synergetic strains will be studied for their plant growth promoting attributes in co-culture and consortia (Pandey et al., 2006).

Induction of antifungal proteins in against test pathogens by using characterized strains for seed bacterization

Surface Sterilized and bacterized seeds will be crushed in a pre-chilled $\left(4^{\circ} \mathrm{C}\right)$ mortar and pestle using acid-sand and extraction buffer ( $\mathrm{pH}-5)$. Crude homogenate will be filtered using nylon filter and centrifuged $\left(10,000 \mathrm{rpm}, 4^{\circ} \mathrm{C}\right)$. The supernatant will be precipitated at $4{ }^{\circ} \mathrm{C}$ overnight by ammonium sulphate and recentrifuged at same conditions. The crude protein (supernatant) so obtained will be then loaded on to well made in sterile PDA/NAM plate pre-spreaded with uniform fungal/bacterial inoculum.

Seed bacterization by plant growth-promoting strains to study their effect on growth parameters by experimental pot/field trials

For seed bacterization, methodology adopted by Arora et al. (2000) will be followed. Pot and field trials of individual strain and consortia along with pathogen infested treatment and a control will be put using a complete randomized block design (RBD). Plant growth parameters such as shoot, root length and biomass along with number of fruits, 
total fruit yield per treatment and reduction in disease incidence will be recorded periodically and analyzed boistatistically. Further elaborate studies will be carried out according to Dubey and Maheshwari (2006).

Shelf-life of consortia will be assessed in carrier for a bioformulation

Characterized strains in different consortia with optimum growth promoting activity will be assessed for shelf-life in economically viable solid carrier to be used as a bioformulation.

\section{Results and Discussion}

\section{Isolation of microorganisms}

Isolation and Identification of Macrophomina phaseolina

The fungal pathogen Macrophomina phaseolina was isolated from disease infected plants of $L$. esculentum. The isolated black colour colonies of $M$. phaseolina were compared with standard cultures of $M$. phaseolina procured from Division of Plant Pathology, IARI, New Delhi and maintained on potato dextrose agar medium at $4^{\circ} \mathrm{C}$ The colonies of $M$. phaseolina on PDA were grayish brown to black, floccose with abundant aerial mycelium and micro-sclerotia nestling amongst the hyphae. Mycelium was umber to chestnut brown eventually becoming dark brown, septate, branched, and composed of barrel shaped or cylindrical hyphal cells. Mycelial growth was followed by sclerotia formations. The sclerotia were abundant, dark brown to jet-black, smooth, irregular in size, composed of dark brown cells with a central rounded pour within mesh of the cells.

Isolation and characterization of native rhizospheric bacteria from $L$. esculentum.

A total of 31 bacterial strains were isolated from the rhizosphere of young and healthy tomato plant collected from the Roshnabad, Haridwar (Uttarakhand). These isolates were abbreviated as LEP25 to LEP31. The standard strains viz., Pseudomonas aeruginosa MTCC1934, Azotobacter vinelandii MTCC124 and Bacillus subtilis MTCC441 were procured from the Institute of Microbial technology (IMTECH), Chandigarh for comparisons.

Table 1: Evaluation of plant growth promoting attributes of LEP11- LEP31

\begin{tabular}{|c|c|c|c|c|c|c|c|}
\hline Strains & IAA & Siderophore & HCN & Chitinase & ACC deaminase & $\beta-1,3-$ Glucanase & Protease \\
\hline LEP11 & + & - & - & - & + & - & + \\
\hline LEP12 & + & + & - & + & - & - & + \\
\hline LEP13 & + & - & + & - & + & + & - \\
\hline LEP14 & - & + & - & - & - & + & + \\
\hline LEP15 & + & - & + & - & - & - & - \\
\hline LEP16 & - & + & - & - & + & + & + \\
\hline LEP17 & ++ & ++ & + & + & + & + & - \\
\hline LEP18 & - & - & + & - & + & - & + \\
\hline LEP19 & + & + & - & + & - & - & + \\
\hline LEP 20 & + & - & + & - & + & + & + \\
\hline LEP21 & ++ & + & ++ & - & - & ++ & + \\
\hline LEP22 & + & + & + & - & - & - & - \\
\hline LEP23 & - & + & - & - & + & + & + \\
\hline LEP24 & + & ++ & + & - & + & + & - \\
\hline LEP25 & + & ++ & + & - & + & + & + \\
\hline LEP26 & + & + & - & - & + & - & - \\
\hline LEP27 & + & - & + & - & + & + & + \\
\hline LEP28 & - & + & + & - & - & + & + \\
\hline LEP29 & + & + & - & - & - & - & - \\
\hline LEP30 & - & + & + & - & + & + & + \\
\hline LEP31 & + & + & + & - & + & ++ & - \\
\hline MTCC1934 & + & + & + & - & + & ++ & - \\
\hline MTCC124 & + & + & + & - & + & + & + \\
\hline MTCC441 & + & + & + & - & + & ++ & - \\
\hline
\end{tabular}

Abbreviations: $-=$ negative, $+=$ positive; IAA $=$ indole-3-acetic acid; siderophore $+=$ small halos $<0.5 \mathrm{~cm}$ wide surrounding colonies, $++=$ medium halos $>0.5 \mathrm{~cm}$ wide surrounding colonies, $+++=$ large halos $>1.0 \mathrm{~cm}$ wide surrounding colonies; HCN = hydrocyanic acid production; $\mathrm{ACC}=1$-aminocyclopropane-1-carboxylate deaminase; Pseudomonas aeruginosa MTCC1934; Azotobacter vinelandii MTCC124; Bacillus subtilis MTCC441. All the PGP activities were performed in triplicate experiments. Values represent an average of three replicates 
On the basis of biochemical characters, the phylogenetic relatedness among the all isolates was assessed by UPGMA cluster (Jaccard's coefficient). All the seven isolates LEP11-LEP17 were showed the similarity with standard cultures in UPGMA clusters analysis. Isolate LEP17 and MTCC1934 were found similar identity and showed 97\% similarity. Isolate LEP12 and LEP14 showed 93\% similarity, while LEP16 found 94\% similar to MTCC1934. Among the isolates of LEP18-LEP24 were found to the similarity in UPGMA cluster. LEP18 showed $97.5 \%$ similarity in phenotypic character with standard culture MTCC124, Whereas LEP21 isolate showed $94.5 \%$ similarity with MTCC124 standard culture (Table 1).

Plant growth promoting (PGP) activities: Direct and indirect plant growth promoting activities of Pseudomonas spp., Azotobacter spp. and Bacillus spp. for plant growth promotion were evaluated. The isolates will also be screened for their plant growth promoting (PGP) activities including phytohormone $\left(\mathrm{IAA}_{3}\right)$ production, phosphate solubilization, HCN production, siderophore production etc. (Chandra et al., 2007).

\section{Lytic enzymatic activity}

(i) Chitinase activity: Chitinase activity of bacterial isolates were determined by the development of clear halo around the inoculated bacterial spots when loaded on chitin $(0.2 \%)$ supplemented medium. Only LEP12 and LEP17 isolates of Pseudomonas sp. strain and LEP19 isolate of Azotobacter sp. strain showed the positive result for the production of chitinase. None of the isolates of Bacillus sp. showed chitinase activity Pseudomonas sp. strain LEP17 $(2.8 \mathrm{U} / \mathrm{ml} / \mathrm{h})$ showed the maximum chitinase activity. Chitinase formation was started after $24 \mathrm{~h}$ of incubation which reached the maximum at $120 \mathrm{~h}$ and on further incubation its activity was declined.

(ii) ACC deaminase production: ACC deaminase producing bacteria were screened based on the enrichment method, where ACC was used as sole nitrogen source. For primary screening, multiple colonies of the same bacterial species were spot inoculated on ACC containing Petri plates. Only single colony was selected and further streaked onto the surface of a fresh Prtri plate containing ACC. All the strains of Pseudomonas sp. (except LEP12, LEP14 and LEP15), Azotobacter sp. (except LEP19, LEP21and LEP22) and Bacillus sp. (except LEP28 and LEP29) were able to grow in minimal medium containing ACC as sole nitrogen.

(iii) $\beta$-1,3-glucanase activity: $\beta$-1,3-glucanase activities were screened by appearance of bacterial growth in the medium supplemented with laminarin as a sole source of carbon. Pseudomonas sp. strains isolates LEP13, LEP14 LEP16 and LEP17, Azotobacter sp. strains LEP20, LEP21, LEP23, LEP24 and Bacillus sp. strains LEP25, LEP27, LEP28, LEP30 and LEP31 of were able to grow on laminarin azure-amended minimal medium that indicate $\beta-1,3$-glucanase production.

\section{Root colonization study}

Pseudomonas sp. strain LEP17 $7^{\text {tet+ }}$, Azotobacter sp. strain LEP $21^{\mathrm{nf}+}$ and Bacillus sp. strain LEP25 $5^{\text {chlo+ }}$ were used to evaluate the root colonization of bacteria. All bacterial strains depicted characteristic pattern of root colonization. The populations of bacteria were slightly increased from its initial single inoculation, combinations of two strains and also in consortium.

In present study, 31 bacterial strains were isolated from the rhizosphere of tomato and characterized morph locally, biochemically and phylogenetic relatedness among the all isolates was assessed (Table 1). A number of workers (Gupta et al., 2001; Bhatia et al., 2003; Kamilova et al., 2005; Dubey et al., 2011; Kumar et al., 2012) were isolated the wide variety of beneficial microorganisms. Some PGPB have been isolated from the rhizosphere of agricultural crops such as potato, tomato, cotton, tea were identified and characterized as Pseudomonas spp.. Some noble strains of Pseudomonas aeruginosa were isolated from the rhizosphere of potato (Gupta et al., 1999; 2002) and sunflower (Bhatia et al., 2003; 2005). Keeping this fact, more strains of Pseudomonas spp. having PGP characters, were isolated from the rhizosphere of tomato (L. esculentum). Initially, Kloepper et al. (1988) identified as plant growth promoting rhizobacteria (PGPR) due to their rapid and aggressive rhizosphere colonization that proved as most powerful inoculants to improve plant growth and crop yield (Shahzad et al., 2010; Wahyudi et al., 2011; Saharan and Nehra, 2011; Zabihi et al., 2011). In our study, Pseudomonas sp. LEP17, Azotobacter sp. strain LEP21, Bacillus sp. strain LEP25 evaluated for antibiotic resistance. 
Table 2: Effect of bacterial isolates LEP17, LEP21 and LEP25 and their consortium on seed germination and vigour Index

\begin{tabular}{|l|c|c|c|}
\hline Treatments & Germination (\%) & Seedling length & Seedling Vigour Index \\
\hline Pseudomonas sp. strain LEP17 & 86.50 & 12.32 & 1065.68 \\
\hline Azotobacter sp. strain LEP21 & 88.36 & 13.08 & 1155.74 \\
\hline Bacillus sp. strain LEP25 & 89.31 & 14.47 & 1292.31 \\
\hline Consortium 1 & 91.25 & 16.50 & 1505.62 \\
\hline Consortium 2 & 92.15 & 16.95 & 1561.94 \\
\hline Consortium 3 & 95.34 & 19.70 & 1878.19 \\
\hline Control & 65.80 & 10.56 & 694.84 \\
\hline
\end{tabular}

Abbreviations: Consortium 1 (Pseudomonas sp. strain LEP17 + Azotobacter sp. strain LEP21), consortium 2 (Pseudomonas sp. strain LEP17+ Bacillus sp. strain LEP25), consortium 3 (Pseudomonas sp. strain LEP17+ Azotobacter sp. strain LEP21+ Bacillus sp. strain LEP25), control (Non-bacterized seeds), Values are the mean of three replicates.

Table 3: Average root colonization of inoculated bacterial strains in the rhizosphere of $L$. esculentum after 30 , 60, and 90 days of sowing

\begin{tabular}{|c|c|c|c|c|c|c|}
\hline \multirow[b]{2}{*}{ Treatments } & \multicolumn{2}{|l|}{30 DAS } & \multicolumn{2}{|l|}{60 DAS } & \multicolumn{2}{|l|}{90 DAS } \\
\hline & $\begin{array}{l}\text { Bacterial } \\
\text { population }\end{array}$ & $\begin{array}{l}\text { Indigenous } \\
\text { population }\end{array}$ & $\begin{array}{l}\text { Bacterial } \\
\text { population }\end{array}$ & $\begin{array}{l}\text { Indigenous } \\
\text { population }\end{array}$ & $\begin{array}{l}\text { Bacterial } \\
\text { population }\end{array}$ & $\begin{array}{l}\text { Indigenous } \\
\text { population }\end{array}$ \\
\hline $\begin{array}{ll}\text { Pseudomonas } & \text { sp. } \\
\text { strain LEP17 } & \\
\end{array}$ & $4.55 \pm 0.23$ & $4.95 \pm 0.18$ & $5.24 \pm 0.40$ & $5.30 \pm 0.13$ & $5.43 \pm 0.22$ & $5.20 \pm 0.16$ \\
\hline $\begin{array}{ll}\text { Azotobacter } & \text { sp. } \\
\text { strain LEP21 } & \\
\end{array}$ & $4.12 \pm 0.26$ & $5.34 \pm 0.24$ & $4.22 \pm 0.53$ & $5.85 \pm 0.26$ & $4.40 \pm 0.23$ & $5.25 \pm 0.22$ \\
\hline $\begin{array}{l}\text { Bacillus sp. strain } \\
\text { LEP25 }\end{array}$ & $4.00 \pm 0.14$ & $5.18 \pm 0.20$ & $4.10 \pm 0.27$ & $5.30 \pm 0.30$ & $4.15 \pm 0.20$ & $5.28 \pm 0.14$ \\
\hline $\begin{array}{r}\text { Consortium 1 LEP17 } \\
\text { LEP21 }\end{array}$ & $\begin{array}{l}4.12 \pm 0.25 \\
3.62 \pm 0.18\end{array}$ & $4.50 \pm 0.24$ & $\begin{array}{l}4.35 \pm 0.20 \\
4.08 \pm 0.05\end{array}$ & $4.61 \pm 0.28$ & $\begin{array}{l}4.55 \pm 0.17 \\
4.26 \pm 0.28\end{array}$ & $4.88 \pm 0.26$ \\
\hline $\begin{array}{r}\text { Consortium } 2 \text { LEP17 } \\
\text { LEP25 }\end{array}$ & $\begin{array}{l}4.40 \pm 0.11 \\
4.58 \pm 0.80 \\
\end{array}$ & $5.23 \pm 0.50$ & $\begin{array}{l}4.51 \pm 0.62 \\
4.64 \pm 0.34 \\
\end{array}$ & $5.60 \pm 0.29$ & $\begin{array}{l}4.83 \pm 0.33 \\
4.76 \pm 0.31 \\
\end{array}$ & $5.65 \pm 0.68$ \\
\hline $\begin{array}{r}\text { Consortium } 3 \text { LEP17 } \\
\text { LEP21 } \\
\text { LEP25 } \\
\end{array}$ & $\begin{array}{l}4.60 \pm 0.61 \\
4.81 \pm 0.13 \\
4.89 \pm 0.18 \\
\end{array}$ & $5.34 \pm 0.10$ & $\begin{array}{l}4.65 \pm 0.28 \\
4.86 \pm 0.24 \\
4.94 \pm 0.18 \\
\end{array}$ & $5.61 \pm 0.41$ & $\begin{array}{l}5.06 \pm 0.38 \\
4.99 \pm 0.67 \\
5.12 \pm 0.60 \\
\end{array}$ & $5.37 \pm 0.45$ \\
\hline
\end{tabular}

The antibiotic resistant maker strains developed for carrying out studies on seed bacterization and root colonization. Plant growth promoting attributes of isolates was determined by bacterization of tomato seeds with Pseudomonas sp. strain LEP17, Azotobacter sp. strain LEP21 and Bacillus sp. strain LEP25. These isolates enhanced the seed germination as compared to control at 7 days after sowing (DAS). The tomato seeds bacterized with LEP $17^{\text {tet+ }}+$ LEP2 $1^{\text {nf }+}$, LEP $17^{\text {tet+ }}+$ LEP $25^{\text {chlo+ }}$ and consortium $\left(\mathrm{LEP} 17^{\mathrm{tet}+}+\mathrm{LEP} 21^{\mathrm{nf}+}+\right.$ LEP $\left.25^{\text {chlo }+}\right)$ showed $92 \%, 95 \%$ and $97 \%$ seed germination, respectively, that was $47 \%, 51 \%$ and $55 \%$ higher than control. Single inoculation, co-inoculation and consortium preparations applied to seed resulted in enhanced seed germination (Table 2).

Pseudomonas sp. strain LEP17 showed resistance to tetracycline $\left(100 \mu \mathrm{g} \mathrm{m}^{-1}\right)$, Azotobacter sp. strain LEP21 to nitrofurantoin $\left(100 \mu \mathrm{g} \mathrm{ml}^{-1}\right)$ and Bacillus sp. strain LEP25 to chloramphenicol $\left(100 \mu \mathrm{g} \mathrm{ml}^{-1}\right)$ and, hence abbreviated as Pseudomonas sp. strain LEP17 $7^{\text {tet+ }}$, Azotobacter sp. strain LEP2 $1^{\text {nft }}$ and Bacillus sp. strain LEP $25^{\text {chlo+ }}$. Presence of the marker strains revealed the effective root colonization (Table 3) and competence in the rhizosphere even in the presence of pathogens by Pseudomonas sp. strain LEP17 $7^{\text {tet+ }}$, Azotobacter sp. strain LEP $21^{\mathrm{nft}}$ and Bacillus sp. strain LEP $25^{\text {chlo+ }}$. The antibiotic marker strains viz., Pseudomonas sp. strain LEP17 $7^{\text {tet+ }}$, Azotobacter sp. strain LEP21 ${ }^{\mathrm{nft}}$ and Bacillus sp. strain LEP $25^{\text {chlot }}$ showed enhanced growth and grain yield of tomato besides showing reduction in disease incidences. Effective root 
Table 4: Effect of Pseudomonas sp. strain LEP17, Azotobacter sp. strain LEP21, Bacillus sp. strain LEP25 and their consortium on growth of $L$. esculentum after 90 days of sowing.

\begin{tabular}{|c|c|c|c|c|c|c|c|c|c|}
\hline \multirow[t]{2}{*}{ Treatments } & \multicolumn{2}{|c|}{ Length (cm) } & \multicolumn{2}{|c|}{ Fresh weight (gm) } & \multicolumn{2}{|c|}{ Dry weight (gm) } & \multirow{2}{*}{$\begin{array}{c}\text { No. of } \\
\text { leaf/plant }\end{array}$} & \multirow{2}{*}{$\begin{array}{c}\text { No. of } \\
\text { fruit/plants }\end{array}$} & \multirow{2}{*}{$\begin{array}{c}\text { No. of } \\
\text { seeds/fruit }\end{array}$} \\
\hline & Shoot & Root & Shoot & Root & Shoot & Root & & & \\
\hline Pseudomonas sp. strain LEP17 & $55.85 * *$ & $6.62 * *$ & $171.36^{* *}$ & $36.71 * *$ & $58.07 * *$ & $12.07 * *$ & 93.00 & $11.67 * *$ & $48.66^{* *}$ \\
\hline Azotobacter sp. strain LEP21 & $57.19 * *$ & $6.78^{* *}$ & $172.89 * *$ & $37.78 * *$ & $59.40 * *$ & $12.48 * *$ & $96.67 * *$ & $12.33 * *$ & $51.00 * *$ \\
\hline Bacillus sp. strain LEP25 & $57.88 * *$ & $7.15 * *$ & $176.39 * *$ & $38.03 * *$ & $59.40 * *$ & $13.74 * *$ & $96.00 *$ & $12.67 * *$ & $52.66 * *$ \\
\hline Consortium 1 & $59.76 * *$ & $7.67 * *$ & $177.44 * *$ & $38.89 * *$ & $60.34 * *$ & $14.91 * *$ & $104.00 * *$ & $13.33 * *$ & $55.00 * *$ \\
\hline Consortium 2 & $61.44 * *$ & $8.17 * *$ & $178.95 * *$ & $41.11 * *$ & $62.85 * *$ & $15.84 * *$ & $108.34 * *$ & $14.67 * *$ & $57.00 * *$ \\
\hline Consortium 3 & $63.96 * *$ & $8.40 * *$ & $183.59 *$ & $45.94 * *$ & $68.32 * *$ & $20.74 * *$ & $121.66^{* *}$ & $15.33 * *$ & $63.00 * *$ \\
\hline Control & 54.08 & 5.55 & 161.45 & 32.98 & 52.75 & 9.72 & 87.33 & 8.33 & 45.33 \\
\hline SEM & 0.259 & 0.702 & 0.328 & 0.195 & 0.226 & 0.188 & 2.036 & 0.496 & 0.608 \\
\hline $\mathrm{CD}$ at $1 \%$ & 1.120 & 0.303 & 1.416 & 0.845 & 0.978 & 0.813 & 8.790 & 2.141 & 2.627 \\
\hline $\mathrm{CD}$ at $5 \%$ & 0.799 & 0.216 & 1.012 & 0.602 & 0.698 & 0.580 & 6.272 & 1.524 & 1.874 \\
\hline
\end{tabular}

Abbreviations: SEM = standard error mean; $C D=$ Critical Difference, Values are mean of 3 randomly selected plants from each set, * significant at $5 \%$, ** significant at $1 \%$ as compared to control, $\mathbf{n s}=$ non-sionificant as compared to control; consortium 1 (Pseudomonas sp. strain LEP17 + Azotobacter sp. strain LEP21); consortium 2 (Pseudomonas sp. strain LEP17+ Bacillus sp. strain LEP25); consortium 3 (Pseudomonas sp. strain LEP17+ Azotobacter sp. strain LEP21+ Bacillus sp. strain LEP25); control (non-bacterized seeds)

Table 5: Antagonistic effect of bacterial isolates LEP17, LEP21 and LEP25 in dual culture plate at $28^{\circ} \mathrm{C}$ against Macrophomina phaseolina

\begin{tabular}{|c|c|c|}
\hline Bacterial isolates & $\begin{array}{c}\text { Incubation period } \\
\text { (h) }\end{array}$ & $\begin{array}{c}\text { Growth inhibition of } \\
\text { M. phaseolina (\%) }\end{array}$ \\
\hline \multirow{3}{*}{ Pseudomonas sp. strain LEP17 } & 48 & 48.16 \\
\cline { 2 - 3 } & 72 & 54.89 \\
\cline { 2 - 3 } & 96 & 58.35 \\
\cline { 2 - 3 } & 120 & 63.31 \\
\hline \multirow{3}{*}{ Azotobacter sp. strain LEP21 } & 48 & 43.89 \\
\cline { 2 - 3 } & 72 & 47.25 \\
\cline { 2 - 3 } & 96 & 49.63 \\
\hline \multirow{3}{*}{ Bacillus sp. strain LEP25 } & 120 & 52.77 \\
\cline { 2 - 3 } & 48 & 44.59 \\
\cline { 2 - 3 } & 72 & 50.91 \\
\cline { 2 - 3 } & 96 & 55.15 \\
\hline
\end{tabular}




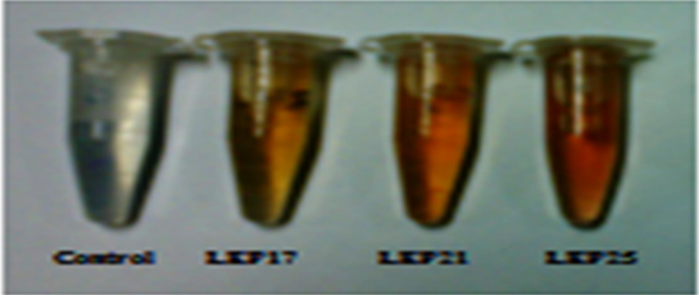

(A)

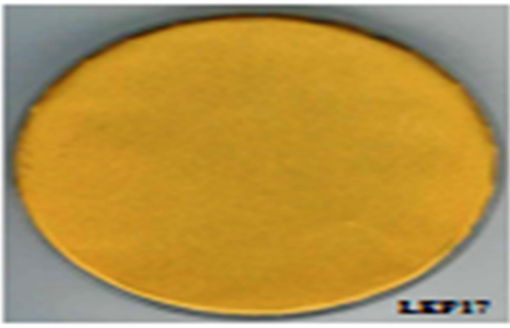

(C)

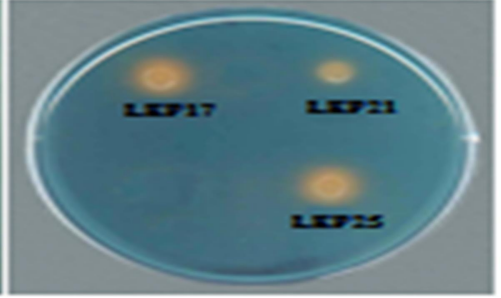

(B)

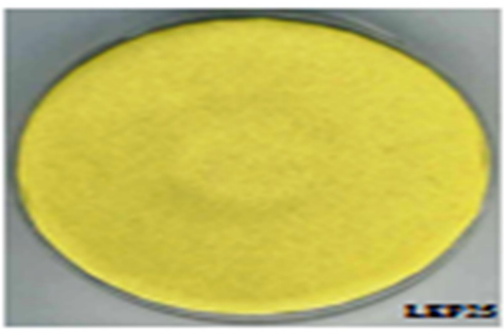

(D)

Figure 1: Plant growth promoting activities of Pseudomonas sp. strain LEP17, Azotobacter sp. strain LEP21 and Bacillus sp. strain LEP25; indole acetic acid (A); siderophore on CAS medium (B) and HCN production (C and D).
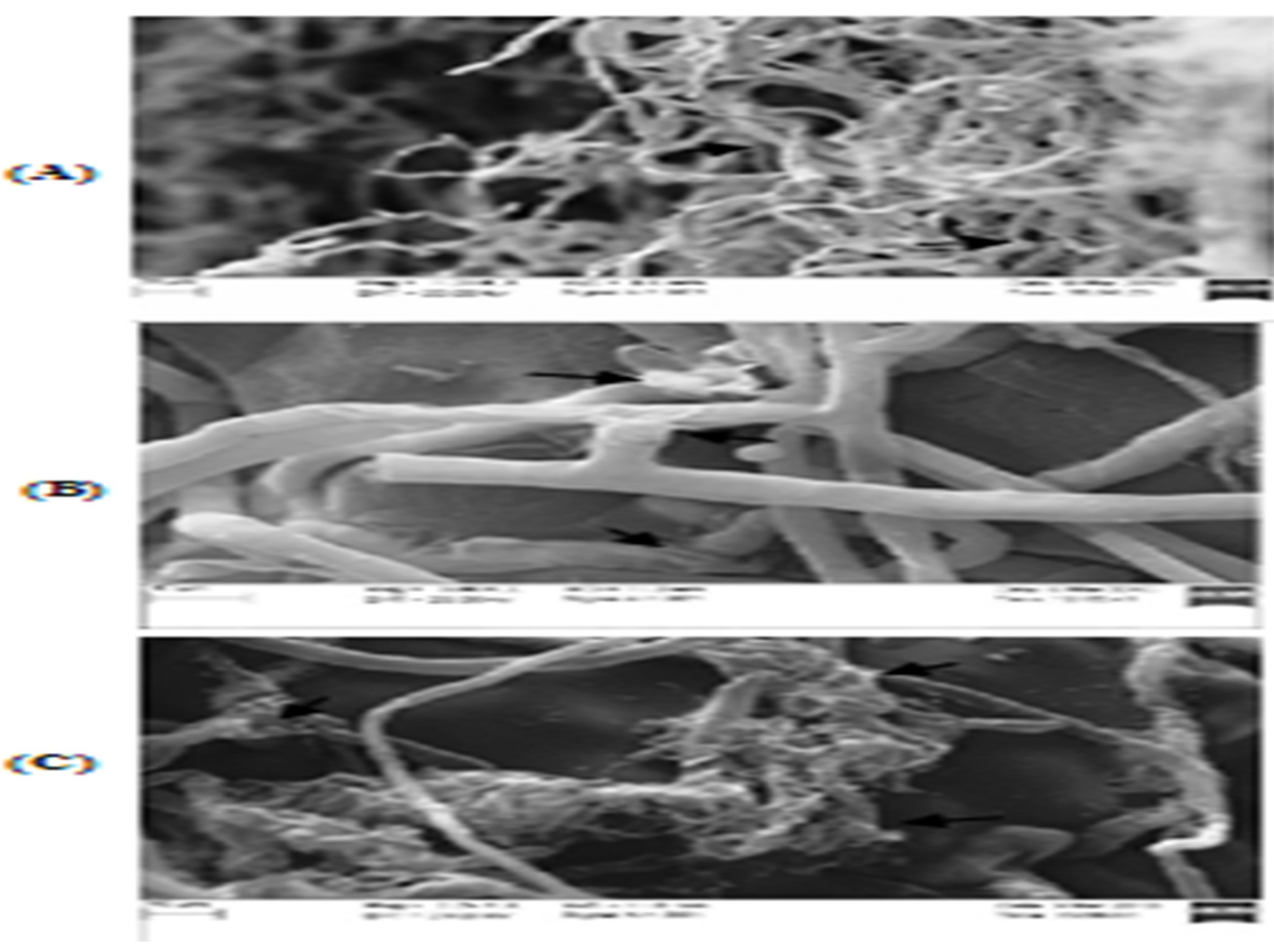

Figure 2: Scanning electron microscopic photographs showing interaction between Pseudomonas sp. strain LEP17 and Macrophomina phaseolina in dual culture. Hyphal lysis (A); hyphal destruction (B); breakage and leakage of cytoplasm (C). 
colonization by Pseudomonas sp. strain LEP $17^{\text {tet+ }}$, Azotobacter sp. strain LEP2 $1^{\mathrm{nft}}$ and Bacillus sp. strain LEP25 $5^{\text {chlo+ }}$ gave enhanced plant growth parameters at 90 DAS (Table 4). Antagonistic effect of bacterial isolates LEP17, LEP21 and LEP25 against Macrophomina phaseolina showed significant plant growth promoting activities and yield attributes (Table 5). The bacteria-mediated production of siderophore, HCN (Figure 1), lytic enzymes and antibiotics suppressed fungal pathogens (Figure 2). Secretion of root exudates enhances rhizobacterial colonization (Chandra et al., 2007) resulting in production of excess amount of siderophore and other compounds which may be involved in biocontrol of phytopathogens (Bais et al., 2006).

\section{Conclusion}

This study has shown that all the three strains and consortiums evaluated in present study, consortium 3 i.e. Pseudomonas sp. LEP17, Azotobacter sp. strain LEP21 and Bacillus sp. strain LEP25 showed significant plant growth promoting activities and yield attributes. The growth promotion provided by these strains was apparently related to improve shoot and root development, which resulted in better nutrient uptake capability and suppression of plant pathogen. All these three strains were superior in this regard because they provided the best and most consistent effects on growth and yield of $L$. esculentum. All these strains Pseudomonas sp. LEP17, Azotobacter sp. strain LEP21, Bacillus sp. strain LEP25 and their consortium seems to be suitable for use as a plant growth promoting and improvement of growth and yield of L. esculentum and suppression of fungal phytopathogen $M$. phaseolina.

\section{Acknowledgement}

The authors wish to thank to UCOST, Dehradun for financial assistance.

\section{References}

Agarwal, V. K., \& Sinclair, J. B. (1997). Principles of seed pathology. CRC Press Inc.Florida, pp. 453- 455.

Arora, N. K., Kumar, V., \& Maheshwari, D. K. (2000). Isolation of both fast and slow growing rhizobia effectively nodulating a medicinal legume, Mucuna pruriens. Symbiosis.29: 121-137.
Bais, H. P., Weir, T. L., Perry, L. G., Gilroy, S., \& Vivanco, J. M. (2006). The role of root exudates in rhizosphere interactions with plants and other organisms. Annu. Rev. Plant Biol., 57, 233-266.

Bhatia, S., Bhatia, S., Dubey, R. C., \& Maheshwari, D. K. (2003). Antagonistic effect of fluorescent pseudomonads against Macrophomina phaseolina that causes charcoal rot of groundnut. Ind. J. Expt. Biol. 41: 1442-1446.

Bhatia, S., Dubey, R. C., \& Maheshwari, D. K. (2005). Enhancement of plant growth and suppression of collar rot of sunflower caused by Sclerotium rolfsii through fluorescent Pseudomonas. Indian Phytopathol, 58(1), 1724.

Chandra, S., Choure, K., Dubey, R.C. \& Maheshwari, D.K. (2007). Rhizosphere competent Mesorhizobium loti MP6 induces root hair curling, inhibits Sclerotinia sclerotiorum and enhances growth of Indian mustard (Brassica campestris). Braz. J. Microbiol. 38: 124-130.

Dhingra, O. D., \& Sinclair, J. B. (1977). An annotated bibliography of Macrophomina phaseolina 1905-1975. An annotated bibliography of Macrophomina phaseolina 1905-1975.

Dubey, R. C., \& Maheshwari, D. K. (2012). Practical microbiology. S. Chand Pvt. Limited.

Dubey, R. C., Maheshwari, D. K., Kumar, V., \& Pandey, R. R. (2012). Growth enhancement of Sesamum indicum L. by rhizosphere-competent Azotobacter chroococcum AZO2 and its antagonistic activity against Macrophomina phaseolina.Archives of Phytopathology and Plant Protection, 45(4), 437-454.

Gupta, C. P., Sharma, A., Dubey, R. C. \& Maheshwari, D. K. (1999). Pseudomonas aeruginosa as a strong antagonist of Macrophomina phaseolina and Fusarium oxysporum. Cytobios. 99: 183-189.

Gupta, C.P., Dubey, R.C. \& Maheshwari, D.K. (2002). Plant growth enhancement and suppression of Macrophomina phaseolina causing charcoal rot of peanut by fluorescent Pseudomonas. Biol. Fertl. Soil 35: 295-301.

Gupta, C. P., Dubey, R. C., Kang, S. C., \& Maheshwari, D. K. (2001). Antibiosis-mediated necrotrophic effect of Pseudomonas GRC 2 against two fungal plant pathogens. Current Science, 91-94.

Hafeez, F. Y., Asad, S., Ahmad, T., \& Malik, K. A. (1995). Host Specificity and characterization of Fast-growing Rhizobia from Macroptilium atropurpureum cv. Siratro in Pakistan. Soil Biology and Biochemistry, 27(4-5), 729-733.

Jeffries, P., Gianinazzi, S., Perotto, S., Turnau, K., \& Barea, J. M. (2003). The contribution of arbuscular mycorrhizal fungi in sustainable maintenance of plant health and soil fertility. Biology and fertility of soils, 37(1), 1-16. 
Kamilova, F., Kravchenko, L. V., Shaposhnikov, A. I., Azarova, T., Makarova, N., \& Lugtenberg, B. (2006). Organic acids, sugars, and L-tryptophane in exudates of vegetables growing on stonewool and their effects on activities of rhizosphere bacteria. Molecular Plant-Microbe Interactions, 19(3), 250-256.

Kloepper, J. W., Lifshitz, R., \& Schroth, M. N. (1988). Pseudomonas inoculants to benefit plant production. ISI ATLAS SCI: ANIM. PLANT SCI., 1(1), 60-64.

Kumar, P., Dubey, R. C., \& Maheshwari, D. K. (2012). Bacillus strains isolated from rhizosphere showed plant growth promoting and antagonistic activity against phytopathogens. Microbiological research, 167(8), $493-$ 499.

Pandey, P.; Saraf, M.; Dubey, R.C. \& Maheshwari, D.K Application of fusaria in agricultural and industrial biotechnology. In Biotechnological applications of microorganisms- a techno-commercial approach (eds. D.K. Maheshwari, R.C. Dubey and S.C. Kang), I.K. International Publishing House 11 (P) Ltd, New Delhi, pp. 199-212.

Saharan, B. S., \& Nehra, V. (2011). Plant growth promoting rhizobacteria: a critical review. Life Sci Med Res, 21(1), 30.
Shahzad, S. M., Khalid, A., Arshad, M., Tahir, J., \& Mahmood, T. (2010). Improving nodulation, growth and yield of Cicer arietinum L. through bacterial ACC-deaminase induced changes in root architecture. European Journal of Soil Biology, 46(5), 342-347.

Skidmore, A. M., \& Dickinson, C. H. (1976). Colony interactions and hyphal interference between Septoria nodorum and phylloplane fungi. Transactions of the British Mycological Society, 66(1), 57-64.

Vincent, J. M. (1970). A manual for the practical study of the root-nodule bacteria. A manual for the practical study of the root-nodule bacteria.

Wahyudi, A. T., \& Astuti, R. I. (2011). Screening of Pseudomonas sp. isolated from rhizosphere of soybean plant as plant growth promoter and biocontrol agent. American Journal of Agricultural and Biological Sciences, 6(1), 134-141.

Zabihi, H. R., Savaghebi, G. R., Khavazi, K., Ganjali, A., \& Miransari, M. (2011). Pseudomonas bacteria and phosphorous fertilization, affecting wheat (Triticum aestivum $\mathrm{L}$.) yield and $\mathrm{P}$ uptake under greenhouse and field conditions. Acta Physiologiae Plantarum, 33(1), 145-152. 